\title{
ANALISIS HUBUNGAN BAURAN PEMASARAN DAN MINAT BELI ULANG KONSUMEN KOPI PADA RIMBUN ESPRESSO \& BREW BAR KOTA PADANG
}

\section{Analysis Of Marketing Mix And Interest In Repurchase Consumer Coffee On Rimbun Espresso \& Brew Bar Padang City}

\author{
Rido Fadilah ${ }^{1}$, Lora Triana $^{2}$, Rina Sari $^{3}$ \\ ${ }^{1}$ Mahasiswa Program Studi Agribisnis Fakultas Pertanian Universitas Andalas, Padang \\ ${ }^{2,3}$ Staff Pengajar Program Studi Agribisnis Fakultas Pertanian Universitas Andalas, Padang \\ "email koresponden: ridofadilah56@gmail.com
}

Received: $17^{\text {th }}$ January 2020. Revised: $28^{\text {th }}$ January 2020. Accepted: $20^{\text {th }}$ April 2020

\begin{abstract}
Abstrak
Penelitian ini bertujuan untuk: (1) mendeskripsikan bauran pemasaran yang telah diterapkan Rimbun Espresso \& Brew Bar dan (2) menganalisa hubungan atribut bauran pemasaran dan minat beli ulang konsumen kopi Rimbun Espresso \& Brew Bar. Metode yang digunakan dalam penelitian ini adalah metode deskriptif kuantitatif. Populasi penelitian ini yaitu konsumen yang mengunjungi Rimbun Espresso \& Brew Bar sebanyak dua kali atau lebih dengan sampel sebanyak 82 orang. Teknik yang digunakan dalam pengambilan sampel yaitu purposive sampling. Data diperoleh dari kuisioner dengan penilaian skala likert dan diuji validitas dan reliabilitasnya. Untuk melihat hubungan bauran pemasaran dan minat beli ulang konsumen digunakan alat analisis statistika uji statistic Chi-Square. Hasil penelitian menunjukan atribut bauran pemasaran yaitu produk, harga, promosi, tempat, sumberdaya, proses, lingkungan fisik adalah sangat baik dan konsumen sangat berminat untuk melakukan pembelian ulang. Pada analisis Chi-Square, variabel bauran sumberdaya, proses, lingkungan fisik memiliki hubungan dengan minat beli ulang konsumen sedangkan variabel bauran produk, harga, promosi, tempat tidak memiliki hubungan. Disarankan kepada Rimbun Espresso \& Brew Bar untuk terus menjaga dan meningkatkan kualitas pelayanan, suasana, kenyamanan, dan fasilitas yang menjadi kebutuhan dan keinginan konsumen ketika berkunjung.
\end{abstract}

Kata kunci: Bauran pemasaran, kedai kopi, minat beli ulang

\begin{abstract}
This study aims to: (1) describe the marketing mix that has been applied by Rimbun Espresso \& Brew Bar and (2) analyze the relationship between marketing mix attributes and repurchase intention of consumers of Rimbun Espresso \& Brew Bar coffee. The method used is quantitative descriptive method. The population is consumers who visit Rimbun Espresso \& Brew Bar twice or more with a sample of 82 people. The technique used in sampling is purposive sampling. Data obtained from questionnaires with Likert scale assessments were tested for validity and reliability. To see the relationship between marketing mix and consumer repurchase interest, a Chi-Square statistical test statistical analysis tool is used. The results showed that the marketing mix attributes namely products, prices, promotions, places, resources, processes, physical environment were very good and consumers were very interested in making repeat purchases. In the Chi-Square analysis, the variable mix of resources, processes, physical environment has a relationship with consumer repurchase interests while the product mix variables, prices, promotions, places have no relationship. Therefore, it is suggested to Rimbun Espresso \& Brew Bar to continue to maintain and improve the quality of service, atmosphere, comfort, and facilities provided what the needs and desires of consumers when visiting.
\end{abstract}

Keywords: Coffee shop,marketing mix,repurchase interes 


\section{PENDAHULUAN}

Kopi merupakan salah satu komoditas perkebunan yang strategis dan berperan penting dalam perekonomian Indonesia. Indonesia merupakan negara produsen kopi keempat terbesar dunia setelah Brazil, Vietnam, dan Colombia. Dari total produksi sekitar 67\% kopinya diekspor sedangkan sisanya (33\%) untuk memenuhi kebutuhan dalam negeri. Tingkat konsumsi kopi dalamnegeri berdasarkan hasil survei LPEM UI tahun 1989 adalah sebesar 500 gram/kapita/tahun. Dewasa ini kalangan pengusaha kopi memperkirakan tingkat konsumsi kopi di Indonesia telah mencapai 800 gram/kapita/tahun. Dengan demikian dalam kurun waktu 20 tahun peningkatan konsumsi kopi telah mencapai 300 gram/kapita/tahun (AEIKI, 2016) Sumatera Barat memiliki potensi cukup besar di bidang perkebunan, karena didukung oleh lahan yang cukup luas dan iklim yang sesuai untuk komoditi perkebunan. Beberapa komoditi unggulan perkebunan rakyat Sumatera Barat adalah karet, kelapa, kelapa sawit, kopi, kakao, gambir, kulit manis dan Nilam. Dari beberapa komoditi unggulan perkebunan spesifik ini enam di antaranya yaitu karet, kelapa, kopi, kakao, kulit manis dan gambir merupakan komoditi perkebunan rakyat yang dominan. Produksi untuk masing-masing komoditi ini mempunyai potensi besar untuk dikembangkan dalam suatu usaha agribisnis yang dapat memperkokoh perekonomian rakyat (Idrus, 2012).

Tingkat konsumsi kopi masyarakat Indonesia pada tahun 2013 sebesar $1.2 \mathrm{~kg}$ perkapita/tahun. Jumlah tersebut masih tergolong rendah dibandingkan dengan negara-negara pengimpor kopi seperti Jepang, USA, Austria, Belgia, Norwegia dan Finlandia dengan jumlah berturut-turut sebesar 3.4 $\mathrm{kg}, 4.3 \mathrm{~kg}, 7.6 \mathrm{~kg}, 8.0 \mathrm{~kg}, 10.6 \mathrm{Kg}$ dan $11.4 \mathrm{~kg}$ perkapita/tahun (Kemenperin RI, 2013.). Namun, selama 4 tahun terakhir, tingkat konsumsi kopi masyarakat Indonesia terus mengalami tren yang positif. Hal tersebut dapat dilihat pada tabel 1 dimana pada tahun 2014, terjadi peningkatan konsumsi sebesar 57 persen dibandingkan tahun 2010 (AEIKI, 2016). Perilaku berbelanja dan menikmati suatu produk berdasarkan trend, emosi, perasaan nyaman, sukacita, kegembiraan merupakan salah satu contoh motif hedonic (Kasnaeny, Achmad, \& Fatchur, 2013).

Kopi merupakan salah satu komoditi perkebunan yang banyak di budidayakan oleh petani dan swasta. Hal ini disebabkan bahwa tanaman kopi memiliki nilai ekonomis yang tinggi dan strategis, baik untuk memberikan peningkatan pendapatan petani bahkan dapat meningkatkan devisa suatu Negara (Sairdama, 2013).

Hal ini membuat kopi bisa dijadikan suatu lapangan usaha bagi para pengusaha ataupun orang-orang yang ingin mengusahakannya, dilihat dari perkembangan budaya minum kopi yang berkembang positif dan telah menjadi kebiasaan bagi masyarakat.

Kota Padang merupakan ibu kota dari Sumatera Barat, hal ini membuat kota Padang menjadi tempat yang pas untuk mengembangkan suatu usaha. Banyak usaha- usaha modern yang hadir dan berkembang di kota ini, termasuk salah satunya adalah usaha kedai kopi (Coffe Shop) dengan berbagai macam konsep yang ada. Hal ini sesuai dengan data dari Badan Penanaman Modal dan Pelayanan Terpadu Satu Pintu (BPMTPSP) kota Padang dimana telah terdapat sebanyak 19 kedai kopi pada tahun 2016 yang berlokasi di kota Padang. Adapun salah satu diantaranya adalah Rimbun Espresso \& Brew Bar.

Rimbun Espresso \& Brew Bar merupakan salah satu coffee shop yang berada di kota Padang. Usaha yang berdiri sejak tahun 2011 ini berlokasi di daerah Jati Baru tepatnya di Jl. Kis Mangunsarkoro yang lokasinya berada tidak jauh dari pusat kota. Rimbun Espresso \& Brew Bar menyediakan menu utama minuman kopi dan olahannya serta beragam makanan pendamping kopi. Walapun memiliki banyak menu lain, kopi tetap menjadi fokus utama dari Rimbun Espresso \& Brew Bar untuk dikembangkan. Adapun minuman kopi yang ada di coffee shop ini mengalami pengembangan menjadi beragam variasi minuman, baik berbahan dasar espresso dari mesin espresso seperti Cappuccino, Latte, Piccolo, dan Americano hingga minuman kopi 
dari alat seduh manual (manual brew) seperti Pour over, Aeropress, Café Press dan lain-lain yang selalu berkembang seiring minat dan antusiasme konsumen yang beragam, baik dari peminum kopi biasa hingga penikmat kopi sejati. Rimbun Espresso \& Brew Bar menggunakan 100 persen biji kopi Arabica dari perkebunan kopi yang ada di Sumatera Barat untuk menghasilkan minuman kopi yang berkualitas dan bercita rasa khas daerah Sumatera Barat.

Sebagai usaha yang menggunakan kopi sebagai bahan baku, Rimbun Espresso \& Brew Bar bukan hanya sebagai usaha yang hanya mencari profit namun juga memikirkan kesejahterahan dari para petani. Hal ini sejalan dengan langkah yang diambil oleh pendiri dari Rimbun Espresso \& Brew Bar yang membantu merintis suatu koperasi untuk para petani kopi yang saat ini dikenal sebagai Koperasi Kopi Solok Radjo.

Dengan segala kegiatan positif yang dilakukan oleh Rimbun Espresso \& Brew Bar, tentunya akan terus memberikan energy positif pula bagi Rimbun Espresso \& Brew Bar untuk terus mengembangkan usahanya. Dalam hal ini, konsumen yang pernah singgah ataupun sudah menjadi pelanggan di Rimbun Espresso \& Brew Bar ini tentunya bukan hanya menilai dari kegiatan-kegiatan positif yang pernah dilakukan oleh Rimbun Espresso \& Brew Bar, tetapi juga melihat bagaimana bauran pemasaran yang diberikan oleh Rimbun Espresso \& Brew Bar kepada konsumennya. Menurut (Abdullah, 2014) jika produk yang ditawarkan melebihi ekspektasi atau harapan konsumen maka konsumen akan merasa puas dan melakukan pembelian ulang pada produk tersebut, dan jika produk yang ditawarkan lebih rendah dari harapan konsumen maka konsumen tersebut akan merasa kecewa dan tidak mau melakukan pembelian ulang terhadap produk.

Berdasarkan hal tersebut peneliti ingin melihat bauran pemasaran (marketing mix) yang telah diterapkan Rimbun Espresso \& Brew Bar dan menganalisis hubungannya dengan minat beli ulang konsumen. Bauran pemasaran merupakan kumpulan alat pemasaran taktis terkendali yang dipadukan perusahaan untuk menghasilkan respon yang diinginkan perusahaan dapat dilakukan perusahaan untuk memengaruhi permintaan produknya (Kotler \& Amstrong, 2008). Dengan mengkaji hubungan bauran pemasaran dengan minat beli ulang konsumen, maka diharapkan dapat diperoleh hubungan antara bauran pemasaran dengan minat beli ulang konsumen. Dari rumusan masalah di atas maka muncul pertanyaan penelitian sebagai berikut:

1. Bagaimana bauran pemasaran yang dilakukan dan minat beli ulang konsumen Rimbun Espresso \& Brew Bar?

2. Bagaimana hubungan atribut-atribut pada bauran pemasaran Rimbun Espresso \& Brew Bar dengan minat beli ulang konsumen?

\section{METODE PENELITIAN}

Penelitian ini akan dilakukan di Rimbun Espresso \& Brew Bar Jl. Kis Mangunsarkoro no. 10 Jati Baru, Padang. Alasan pemilihan tempat ini adalah karena Rimbun Espresso \& Brew Bar ini merupakan salah satu penggagas dari koperasi Solok Radjo dan sebagai coffe shop yang sudah lama mengembangkan bisnis usaha kopi local Sumatera Barat di kota Padang. Penelitian dilakukan sejak tanggal 25 November 2019 sampai 24 Desember 2019. Metode yang digunakan dalam penelitian ini adalah metode survei. Metode survei adalah pengamatan atau penyelidikan yang kritis untuk mendapatkan keterangan yang baik terhadap suatu persoalan tertentu di dalam daerah atau lokasi tertentu, atau studi ekstensif yang dipolakan untuk memperoleh informasi yang dibutuhkan (Daniel, 2005). Penarikan sampel responden dipilih dengan metode non-probability sampling. Metode ini dipilih karena tidak semua anggota populasi memiliki kesempatan yang sama untuk menjadi responden. Teknik pengambilan sampel yang digunakan adalah purposive sampling yaitu teknik pengambilan sampel berdasarkan kriteria yang telah 
dirumuskan terlebih dahulu oleh peneliti (Nazir, 2005). Jumlah sampel yaitu sebanyak 82 orang didapatkan dengan rumus Slovin dengan derajat kebebasan $10 \%$. Data dianalisis secara kualitatif dan kuantitatif.

\section{HASIL DAN PEMBAHASAN}

\section{Gambaran Umum Tempat Penelitian}

Rimbun Espresso \& Brew Bar pada awalnya bernama Rumah Kopi Nunos yang berdiri sejak tahun 2011, yang dirintis oleh seorang pencinta kopi bernama Allan Arthur. Berlokasi di Jl. Kis Mangunsarkoro A/10. Nama Rimbun Espresso \& Brew Bar sendiri lahir pada tahun 2014, karena ada perubahan orientasi bisnis oleh pendiri, yaitu ingin lebih menggunakan produk kopi lokal Sumatera Barat sebagai bahan baku dari produk yang disajikannya.

\section{Struktur Organisasi}

Dalam menjalankan kegiatan usahanya, Rimbun Espresso \& Brew Bar memiliki struktur dan susunan organanisasi. Semua orang yang termasuk di dalam organisasi usaha Rimbun, bertanggung jawab atas tugasnya masing-masing dan saling membantu satu sama lain. Rimbun Espresso \& Brew Bar memiliki struktur seperti pada Gambar 1. General Manajer dipegang oleh Yogi Artha yang merupakan saudara dari Allan Arthur (pemilik) Rimbun. Rimbun Espresso \& Brew Bar memiliki 10 orang karyawan termasuk manajer. Pengelolaan Rimbun dipercayakan kepada Yogi sebagai manajer yang bertanggung jawab atas seluruh operasional dan karyawan Rimbun Espresso \& Brew Bar.

\section{Uji Validitas dan Reabilitas}

Hasil uji validitas dari 10 responden dengan 28 indikator yang ditentukan pada pengukuran bauran pemasaran dan minat beli ulang, keseluruhan indikator dinyatakan valid karena nilai $\mathrm{r}_{\text {hitung }}$ lebih besar dari rable yaitu sebesar 0,632 dengan $a=0,05$. Setelah dilakukan uji validitas, selanjutnya diteruskan kepada uji reliabilitas. Hasil dari uji reliabilitas pada instrumen yang digunakan pada penelitian ini dinyatakan realibel. Nilai Cronbach's Alpha uji reliabilitas pada kuisioner bauran pemasaran dan minat beli ulang lebih besar dari 0,60 yaitu sebesar 0,91 .

\section{Deskripsi Bauran Pemasaran}

Deskripsi bauran pemasaran dan minat beli ulang

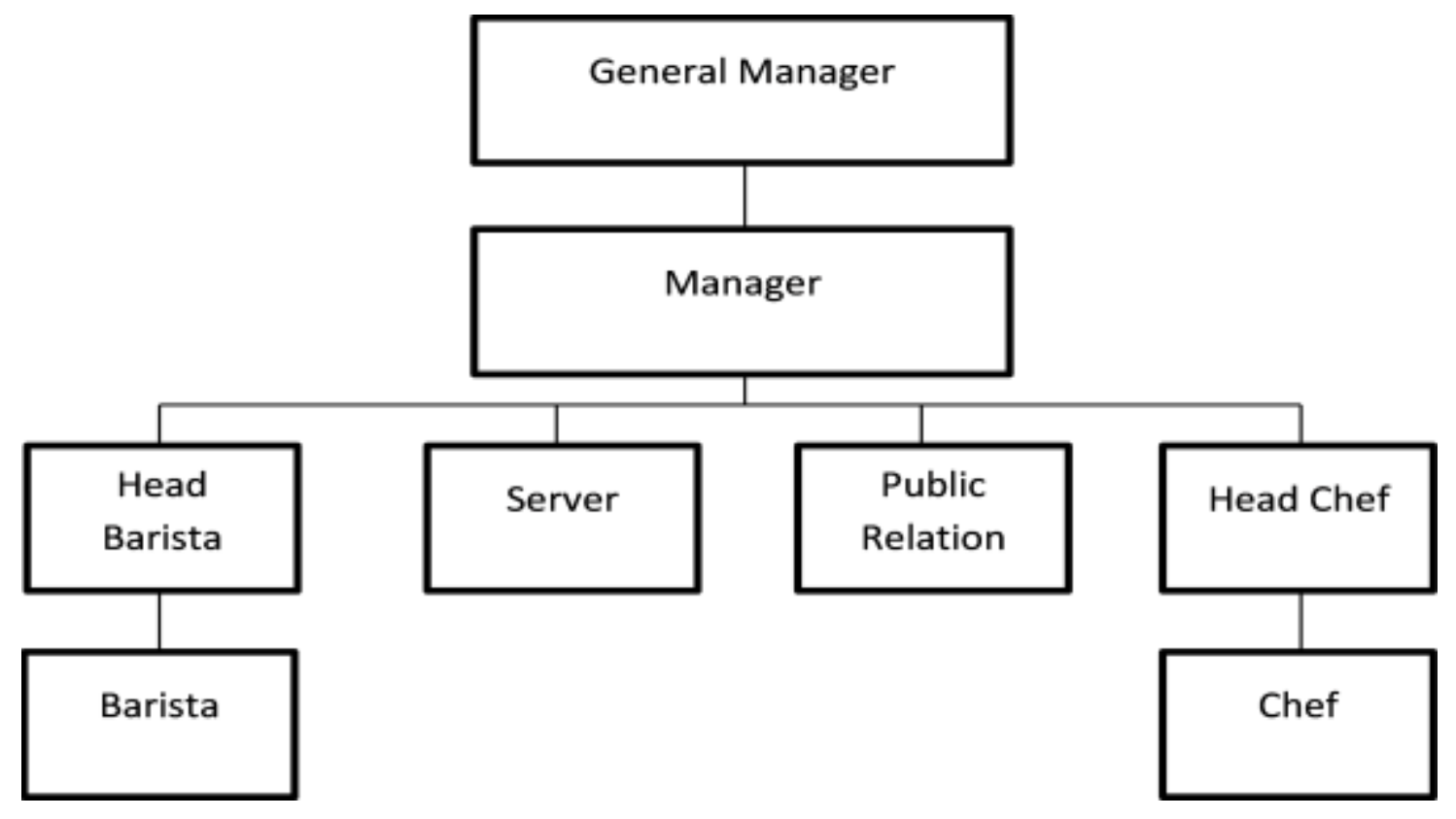

Gambar 1: Struktur Organisasi Rimbun Espresso \& Brew Bar 
konsumen Rimbun Espresso \& Brew Bar dapat dilihat melalui penilaian kuisioner yang telah diisi oleh responden. Kemudian kuisioner ditabulasikan dan diberikan kategori sesuai dengan ketentuan yang telah ditetapkan dengan tujuan agar memudahkan peneliti untuk menggambarkan tentang penilaian responden terhadap bauran pemasaran yang telah diterapkan oleh Rimbun Espresso \& Brew Bar. Dan penilaian responden terhadap tujuh atribut bauran pemasaran dapat dilihat pada Tabel 1 .

Rimbun Espresso \& Brew Bar menyediakan berbagai produk kopi dari Sumatera Barat. Produk kopi yang ditawarkan bervariasi seperti Es Kopi Tanpa Susu, Cappucino, Flat White, Café Latte, Café Mocca, Americano, Picolo, Espresso, Caramel Machiato, Affogato, Single Origin, Vietnam Drip, Cold Brew. Produk kopi yang digunakan dibeli dari koperasi Solok Radjo dalam bentuk biji dan diolah sendiri menjadi bubuk dengan menggunakan bantuan mesin roasting dan jika ketersediaan di koperasi tersebut kurang maka Rimbun Espresso \& Brew Bar mencari ke petani lain yang ada di Sumatera Barat. berada pada kategori sangat baik. Hal ini menunjukkan bahwa produk yang disajikan sudah memenuhi keinginan dari responden, baik itu dari segi selera, kualitas, variasi, maupun rasa khas dari kopi minang yang menjadi andalan dari Rimbun Espresso \& Brew Bar ini.

\section{Harga (Price)}

Harga yang ditetapkan oleh Rimbun Espresso \& Brew Bar bervariasi. Harga pada produk kopi mereka semua sama yang membedakannya adalah teknik penyeduhannya. Produk kopi yang dijual mulai dari yang paling murah Rp.15.000,- dan yang paling mahal Rp.29.000,-. Harga ini sudah merupakan standar harga kopi yang hampir sama dengan harga pesaingnya, yang membedakan adalah produk yang digunakan dalam tiap menunya dan barista yang membuatkan menunya.

Harga yang ditawarkan oleh Rimbun Espresso \& Brew Bar. Berdasarkan hasil penelitian, dapat dilihat pada Tabel 1 bahwa sebagian besar dari responden berada pada kategori sangat baik. Hal tersebut dikarenakan harga produk yang ditawarkan saat ini

Tabel 1. Distribusi Frekuensi Kategori Penilaian Konsumen Pada Bauran Pemasaran

\begin{tabular}{llllllll}
\hline & & \multicolumn{2}{c}{ Baik } & \multicolumn{2}{c}{ Sangat Baik } & \multicolumn{2}{c}{ Total } \\
\cline { 3 - 8 } No & Variabel & $\mathbf{n}$ & $\boldsymbol{\%}$ & $\mathbf{N}$ & $\mathbf{\%}$ & $\mathbf{n}$ & $\boldsymbol{\%}$ \\
\hline 1 & Produk & 18 & 22 & 64 & 78 & 82 & 100 \\
2 & Harga & 13 & 16 & 69 & 84 & 82 & 100 \\
3 & Tempat & 32 & 39 & 50 & 61 & 82 & 100 \\
4 & Promosi & 32 & 39 & 50 & 61 & 82 & 100 \\
5 & Sumberdaya & 17 & 21 & 65 & 79 & 82 & 100 \\
6 & Proses & 19 & 23 & 63 & 77 & 82 & 100 \\
7 & Lingkungan Fisik & 38 & 46 & 44 & 54 & 82 & 100 \\
\hline
\end{tabular}

Setelah biji kopi di roasting kopi di seduh dengan beraneka ragam teknik penyeduhan seperti tubruk, french press, aero press, V60 dan cold brew.

Berdasarkan hasil penelitian ini, dapat dilihat pada Tabel 1 bahwa sebagian besar dari responden yang memang tidak terlalu jauh berbeda dengan para pesaing yang ada di sekitar Rimbun Espresso \& Brew Bar dan masih terjangkau oleh konsumen, kemudian responden menganggap bahwa harga yang 
ditetapkan sudah sesuai dengan kualitas produk yang diberikan.

\section{Tempat (Place)}

Lokasi Rimbun Espresso \& Brew Bar berada di Jalan Kis Mangunsarkoro A/10, Jati Baru, Kota Padang. Lokasi Rimbun Espresso \& Brew Bar dapat dikatakan strategis karena berada di tengah kota yang di sekitarnya terdapat perkantoran, sekolah, dsb. Lokasi ini juga sering dilalui oleh kendaraan sehingga mudah ditemui dan akses menuju lokasi pun mudah. Rimbun Espresso \& Brew Bar buka setiap hari mulai pukul 11.00 sampai 01.00 .

Berdasarkan hasil penelitian, dapat dilihat pada Tabel 1 bahwa sebagian besar dari responden berada pada kategori sangat baik. Dengan demikian lokasi dari Rimbun Espresso \& Brew Bar dapat dikatakan strategis karena lokasi Rimbun Espresso \& Brew Bar berada di tengah kota dan juga banyak aktifitasaktifitas seperti aktifitas persekolahan, perkantoran, dsb, yang ada di sekitarnya.

\section{Promosi (Promotion)}

Promosi yang dilakukan untuk saat ini yaitu melalui media sosial dan sebatas mengenalkan keberadaan cafe serta keseruan yang terjadi setiap harinya. Rimbun Espresso \& Brew Bar juga melakukan promosi dengan cara mengikuti event-event kopi yang ada di Kota Padang maupun di luar kota serta juga mengadakan kompetisi dengan nama "Liga Seduh Rimbun" dengan tujuan untuk melakukan promosi dan juga memperkuat silaturahmi dengan coffe shop lainnya yang ada di Sumatera Barat. Konsumen yang datang ke Ruang kopi kebanyakan mendapat informasi dari mulut ke mulut (word of mouth) melalui teman dan keluarga.

Berdasarkan hasil penelitian, pada Tabel 1 dapat dilihat bahwa sebagian besar dari responden berada pada kategori sangat baik. Hal ini menunjukkan bahwa responden mengetahui tentang promosipromosi yang dilakukan oleh Rimbun Espresso \& Brew Bar baik itu di media social maupun di eventevent kopi yang ada, dan juga ada responden yang pernah mendapatkan diskon harga ketika berkunjung pada hari kemerdekaan, anniversary Rimbun Espresso \& Brew Bar, dan hari spesial lainnya.

\section{Sumberdaya (People)}

Rimbun Espresso \& Brew Bar memiliki 10 orang karyawan sudah termasuk manager. Setiap konsumen yang datang selalu di sambut dan langsung di layani. Rimbun Espresso \& Brew Bar selalu menekankan kepada kualitas pelayanan dan permintaan konsumen. Maka dari itu barista yang ada harus siap terhadap permintaan yang diinginkan konsumen. Selain itu, barista selalu ditekankan untuk selalu tersenyum dan ramah kepada pembeli. Untuk kualitas kopi sendiri, barista yang ada sudah mempunyai pengalaman dan pengetahuan yang luas tentang meracik kopi.

Berdasarkan hasil penelitian, pada Tabel 1 bisa dilihat bahwa sebagian besar dari responden berada pada kategori sangat baik. Hal ini menunjukkan pelayanan yang di berikan oleh Rimbun Espresso \& Brew Bar sudah sesuai dengan ekspektasi responden karena mayoritas konsumen yang menjadi responden yang berkunjung ke Rimbun Espresso \& Brew Bar merasa puas dengan pelayanan yang mereka terima.

\section{Proses (Process)}

Rimbun Espresso \& Brew Bar mengedepankan pelayanan pada pengunjung sehingga para karyawan di tuntut untuk bekerja cepat dan juga ramah dalam melayani konsumen seperti kecepatan dalam membuat menu yang di pesan konsumen sehingga konsumen tidak terlalu lama menunggu dan menyambut setiap konsumen yang datang dengan ramah dan sopan. Perkembangan zaman juga membuat Rimbun Espresso \& Brew Bar mengembangkan cara bertransaksinya yang bisa dilakukan dengan kartu kredit dan juga uang digital serta menyediakan produk kopi delivery di beberapa aplikasi online. Hal tersebut penting karena dalam menjalankan bisnis di bidang cafe selain memiliki produk yang enak pelayanan pun harus di kedepankan agar konsumen yang datang berkunjung merasa puas dan yang tidak bisa berkunjung juga masih bisa menikmati produk kopi. 
Berdasarkan hasil penelitian, pada Tabel 1 bisa dilihat bahwa sebagian besar dari responden berada pada kategori sangat baik. Hal ini menunjukkan penilaian konsumen yang menjadi respon merasa senang dengan mudah dan cepatnya penyediaan pesanan, selain itu juga media pembayaran yang bisa melalui uang digital juga memudahankan konsumen dalam bertransaksi. Responden yang menjadi konsumen juga menyatakan bahwa tersedianya Rimbun Espresso \& Brew Bar di aplikasi online, membuat konsumen mudah jika ingin menikmati produk kopi namun tidak bisa berkunjung ke Rimbun Espresso \& Brew Bar.

\section{Lingkungan Fisik (Physical Evidence)}

Lingkungan fisik adalah keadaan atau kondisi yang di dalamnya juga termasuk suasana. Adapun suasana yang ingin ditonjolkan disana adalah dengan tema vintage modern dengan menggunakan cahaya lampu yang tidak begitu terang namun bagus jika ingin mengabadikan gambar. Furniture yang digunakan juga rata-rata terbuat dari kayu, ditambah terdapat banyak lukisan dan quotes yang menyejukkan mata sehingga pelanggan pun menjadi betah berlama lama menikmati suasana disana.

Berdasarkan hasil penelitian, pada Tabel 1 bisa dilihat bahwa sebagian besar dari responden berada pada kategori sangat baik. Hal ini menandakan bahwa responden yang menjadi konsumen merasa nyaman tata letak layout yang di terapkan oleh Rimbun Espresso \& Brew Bar. Konsumen juga menyatakan dengan struktur bangunan yang cukup kokoh membuat konsumen merasa aman ketika melakukan kunjungan.

\section{Hubungan Bauran Pemasaran dan Minat Beli Ulang}

Untuk melihat hubungan atribut-atribut bauran pemasaran $(\mathrm{X})$ dan minat beli ulang konsumen (Y), maka digunakan analisis statistika yaitu Uji ChiSquare. Dari analisa yang telah dilakukan didapatkan hasil seperti pada Tabel 2.

\section{Hubungan produk dan minat beli ulang}

Menurut (Kotler, 2005) produk adalah apapun yang dapat ditawarkan untuk pasar yang dapat memenuhi keinginan atau kebutuhan tertentu. Produk tidak hanya meliputi atribut fisik saja, tetapi juga mencakup sifat-sifat nonfisik, misalnya harga, nama penjual, semua unsur tersebut dipandang sebagai alat pemuas kebutuhan.

Pada tabel 2 dapat dilihat hasil dari Asymptotic Significance (2-sided) produk yaitu sebesar 0.259, angka ini lebih besar dari $\alpha$ dengan nilai 0.05 , maka tidak terdapat hubungan antara variabel bauran produk dan minat beli ulang konsumen yang artinya Ha pada ditolak dan H0 diterima. Ini menunjukkan meskipun penilaian konsumen pada bauran produk baik tetapi tidak berhubungan dengan minat beli ulang karena produk tidak menjadi prioritas utama konsumen melakukan dalam melakukan pembelian ulang. Hal ini didukung dengan sebagian responden

Tabel 2. Hasil Uji Chi-Square

\begin{tabular}{lllll}
\hline Variabel & $\begin{array}{l}\text { Pearson Chi- } \\
\text { Square } \\
\text { Value }\end{array}$ & $\begin{array}{l}\text { Asymptotic } \\
\text { Significance (2-sided) }\end{array}$ & Nilai a & Korelasi \\
\hline Produk & 1,27 & 0,26 & 0.05 & Tidak Berhubungan \\
Harga & 0,03 & 0,86 & 0.05 & Tidak Berhubungan \\
Tempat & 0,79 & 0,37 & 0.05 & Tidak Berhubungan \\
Promosi & 0,19 & 0,66 & 0.05 & Tidak Berhubungan \\
Sumberdaya & 6,20 & 0,01 & 0.05 & Berhubungan \\
Proses & 6,04 & 0,01 & 0.05 & Berhubungan \\
Lingkungan Fisik & 5,63 & 0,02 & 0.05 & Berhubungan \\
\hline
\end{tabular}


yang menyatakan bahwa merasa penasaran dengan rasa dari produk kopi yang ada, karena kopi yang sedang menjadi trend pada saat ini. Sehingga apabila rasa yang dirasakan tidak sesuai dengan ekspektasi responden bukan menjadi masalah yang besar.

\section{Hubungan harga dan minat beli ulang}

Menurut (Kotler \& Amstrong, 2001) harga merupakan sejumlah uang yang ditukarkan untuk produk atau jasa, atau sejumlah nilai yang ditukarkan konsumen untuk sejumlah manfaat dengan memiliki atau menggunakan suatu barang atau jasa. Bila suatu produk mengharuskan konsumen mengeluarkan biaya yang lebih besar dibanding manfaat yang diterima, maka yang terjadi adalah bahwa produk tersebut memiliki nilai negatif. Konsumen mungkin akan menganggap sebagai nilai yang buruk dan kemudian akan mengurangi konsumsi terhadap produk tersebut.

Hasil dari Asymptotic Significance (2-sided) yaitu sebesar 0.858 , angka ini lebih besar dari $\alpha$ dengan nilai 0.05 , maka tidak terdapat hubungan antara variabel bauran harga dan minat beli ulang konsumen yang artinya Ha ditolak dan $\mathrm{HO}$ diterima. Ini menunjukkan meskipun penilaian konsumen pada bauran harga sangat baik tetapi tidak berhubungan dengan minat beli ulang karena harga tidak menjadi prioritas utama konsumen melakukan dalam melakukan pembelian ulang. Hal ini didukung dengan penyataan responden bahwa harga yang diterapkan oleh Rimbun Espresso \& Brew Bar ini hampir sama dengan harga yang ditawarkan oleh kedai-kedai kopi yang lainnya, sehingga responden tidak menganggap harga menjadi masalah apabila masih sesuai dengan produk dan pelayanan yang diberikan.

\section{Hubungan tempat dan minat beli ulang}

Menurut (Lupiyoadi, 2013) lokasi berarti berhubungan dengan dimana perusahaan harus bermarkas dan melakukan operasi atau kegiatannya. Lokasi merupakan salah satu faktor terpenting yang mempengaruhi perkembangan suatu bisnis, termasuk cafe. Lokasi yang strategis akan mendatangkan banyak konsumen sehingga mampu menaikkan grafik baik penjualan maupun omzet dari bisnis itu sendiri.

Hasil dari Asymptotic Significance (2-sided) harga yaitu sebesar 0.373, angka ini lebih besar dari a dengan nilai 0.05 , maka tidak terdapat hubungan antara variabel bauran tempat dan minat beli ulang konsumen yang artinya $\mathrm{Ha}$ pada ditolak dan $\mathrm{HO}$ diterima. Ini menunjukkan meskipun penilaian responden pada bauran tempat sangat baik tetapi tidak berhubungan dengan minat beli ulang karena tempat tidak menjadi prioritas utama konsumen melakukan dalam melakukan pembelian ulang. Hal ini didukung oleh pernyataan responden bahwa tempat bukan menjadi masalah untuk berkunjung, karena akses transportasi seperti kendaraan pribadi yang dimiliki para responden.

\section{Hubungan promosi dan minat beli ulang}

Menurut (Tjiptono, 2008) tujuan utama dari promosi adalah menginformasikan, mempengaruhi dan membujuk, serta mengingatkan pelanggan sasaran tentang perusahaan dan bauran pemasarannya.

Hasil dari Asymptotic Significance (2-sided) yaitu sebesar 0.664 , angka ini lebih besar dari $\alpha$ dengan nilai 0.05 , maka tidak terdapat hubungan antara variabel bauran promosi dan minat beli ulang konsumen yang artinya Ha ditolak dan $\mathrm{HO}$ diterima. Ini menunjukkan meskipun penilaian konsumen pada bauran promosi sangat baik tetapi tidak berhubungan dengan minat beli ulang karena promosi tidak menjadi prioritas utama konsumen melakukan dalam melakukan pembelian ulang. Hal ini dikarenakan sebagian dari responden yang menyatakan mengunjungi Rimbun Espresso \& Brew Bar ini merupakan rekomendasi dari temannya bukan karena tertarik akan promosi yang telah dilakukan, meskipun para responden tahu tentang promosi yang telah dilakukan oleh Rimbun Espresso \& Brew Bar.

\section{Hubungan sumberdaya dan minat beli ulang}

Menurut (Lupiyoadi, 2013) untuk mencapai kualitas terbaik pegawai harus dilatih untuk menyadari pentingnya pekerjaan mereka, yaitu memberikan konsumen kepuasan dalam memenuhi kebutuhannya. 
Hasil dari Asymptotic Significance (2-sided) yaitu sebesar 0.013, angka ini lebih kecil dari $\alpha$ dengan nilai 0.05 , maka terdapat hubungan antara variabel bauran sumberdaya dan minat beli ulang konsumen yang artinya $\mathrm{HO}$ ditolak dan Ha diterima. Hal ini menunjukkan respon positif dari responden terhadap bauran sumberdaya Rimbun Espresso \& Brew Bar, hal ini didukung oleh pernyataan responden bahwa pelayanan yang dilakukan oleh anggota Rimbun Espresso \& Brew Bar dari awal pemesanan hingga penyediaan menu pesanan responden cukup cepat sehingga responden bisa menikmati menu yang dipesan tanpa harus menunggu lama.

\section{Hubungan proses dan minat beli ulang}

Menurut (Kotler \& Keller, 2009) Proses dalam pemasaran jasa terkait dengan kualitas jasa yang diberikan, terutama dalam hal sistem penyampaian jasa.

Hasil dari Asymptotic Significance (2-sided) yaitu sebesar 0.014, angka ini lebih kecil dari $\alpha$ dengan nilai 0.05 , maka terdapat hubungan antara variabel bauran proses dan minat beli ulang konsumen yang artinya H0 ditolak dan $\mathrm{Ha}$ diterima. Hal ini menunjukkan respon positif dari responden terhadap bauran proses Rimbun Espresso \& Brew Bar, hal ini didukung oleh pernyataan responden bahwa kemudahan dan kecepatan sangat baik, pembayaran melalui akun digital, e-money, dsb sangat memudahkan konsumen dalam pembayaran.

\section{Hubungan lingkungan fisik dan minat beli ulang}

Physical evidence merupakan lingkungan dimana suatu perusahaan memberikan layanannya dan lokasi dimana perusahaan dapat berinteraksi dengan konsumen, serta berbagi komponen yang tampak (tangible) dalam menunjang kinerja dan kelancaran pelayanan (Zeithaml, Bitner, \& Gremler, 2006).

Hasil dari Asymptotic Significance (2-sided) yaitu sebesar 0.018, angka ini lebih kecil dari $\alpha$ dengan nilai 0.05 , maka terdapat hubungan antara variabel bauran lingkungan fisik dan minat beli ulang konsumen yang artinya $\mathrm{H} 0$ ditolak dan $\mathrm{Ha}$ diterima. Hal ini menunjukkan respon positif dari responden terhadap lingkungan fisik dari Rimbun Espresso \& Brew Bar, hal ini didukung oleh pernyataan responden bahwa kebanyakan dari responden melakukan kunjungan dengan waktu yang cukup lama, maka dari itu suasana, fasilitas dan konsep tata ruang yang telah disediakan oleh Rimbun Espresso \& Brew Bar dapat membuat responden merasa nyaman dan menikmati suasananya.

\section{KESIMPULAN}

\section{Kesimpulan}

Berdasarkan hasil penelitian yang telah dilakukan, maka dapat disimpulkan sebagai berikut:

Bauran pemasaran Rimbun Espresso \& Brew bar sudah sangat baik. Hal ini di tunjukkan dari skor distribusi frekuensi kategori penilaian konsumen rata-rata pada bauran pemasaran yang mayoritas sudah berada pada kategori sangat baik. Skor distribusi frekuensi kategori penilaian konsumen terbesar berada pada bauran harga yaitu sebesar 69 orang dengan persentase $84 \%$ dan distribusi frekuensi kategori penilaian konsumen terendah berada pada bauran lingkungan fisik yaitu sebanyak 44 orang dengan persentase $54 \%$.

Dari hasil pengolahan data dengan analisis Chi Square menggunakan SPSS diperoleh hasil antara hubungan bauran pemasaran dengan minat beli ulang konsumen didapatkan bahwa pada bauran produk, bauran harga, bauran promosi dan bauran tempat tidak memiliki hubungan dengan minat beli ulang, dengan nilai Asymptotic Significance sebesar 0.259, $0.858,0.373$, dan 0.664 lebih besar dari a sebesar 0.05. Hal ini dikarenakan bauran tersebut bukan menjadi prioritas konsumen untuk melakukan pembelian ulang di Rimbun Espresso \& Brew Bar. Kemudian pada bauran sumberdaya, bauran proses, dan bauran lingkungan fisik memiliki hubungan dengan minat beli ulang konsumen kopi, dengan nilai Asymptotic Significance sebesar 0.013, 0.014, 
0.018 lebih kecil dari a sebesar 0.05. Hal ini dikarenakan konsumen menganggap penting bauran tersebut untuk diperhatikan agar bisa lebih meningkatkan minat beli konsumen ke Rimbun Espresso \& Brew Bar.

\section{Saran}

Berdasarkan hasil penelitian tentang hubungan bauran pemasaran dengan minat beli konsumen kopi pada Rimbun Espresso \& Brew Bar, maka terdapat beberapa saran sebagai masukan dan pertimbangan dalam pengambilan keputusan yang bermanfaat bagi Rimbun Espresso \& Brew Bar:

Rimbun Espresso \& Brew Bar harus terus berinovasi pada bentuk fisik dan tampilan layout café, karena pada analisis Chi Square bauran lingkungan fisik memiliki hubungan dengan minat beli ulang konsumen. Dan juga mesin penghisap asap rokok pada kawasan bebas merokok juga harus di check secara berkala, mengingat bahwa area café yang berada didalam ruangan supaya bisa menstabilkan sirkulasi udara.

Rimbun Espresso \& Brew Bar perlu mempertimbangkan penambahan variasi pada menu kopi, karena dengan semakin banyaknya coffe shop bermunculan dan akan menimbulkan persaingan. Maka dari itu perlu ada inovasi baru untuk menumenu kopi agar tetap bisa bersaing dengan sehat bersama para kompetitor.

\section{Daftar Pustaka}

Abdullah, M. (2014). Manajemen dan Evaluasi Kinerja Karyawan. Yogyakarta: Penerbit Aswaja Pressindo.

AEIKI. (2016). Industri Kopi Indonesia. http://www.aekiaice.org / page / industri-kopi/id.

Daniel, M. (2005). Metode Penelitian Sosial Ekonomi. Jakarta: Bumi Aksara.

Idrus, R. (2012). Tren Perkembangan Komoditi Unggulan Perkebunan Rakyat Di Sumatera Barat. Jurnal Tren Komoditi Unggulan, Vol. XII.

Kasnaeny, K., Achmad, D., \& Fatchur. (2013). Patronage Buying Motives of Coffee shop's Consumers. IOSR Journal of Business and Management (IOSR-JBM), 8 (3), 19-22.

Kemenperin RI. (2013.). Produksi kopi nusantara ketiga terbesar di dunia. www.kemenperin.go.id.

Kotler. (2005). Manajemen Pemasaran. Jilid 1 Edisi Kesebelas. Jakarta: PT. Indeks.
Kotler, \& Amstrong. (2008). Prinsip - Prinsip Pemasaran Jilid 1. (Alih Bahasa: Bob Sabran, M.M). Jakarta: Penerbit Erlangga.

Kotler, P., \& Keller, K. (2009). Manajemen Pemasaran. (E. ke-13, Penyunt.) Jakarta: Erlangga.

Kotler; Amstrong. (2001). Prinsip-Prinsip Pemasaran, Edisi Kedelapan Jilid Satu. (T. O. M.B.A., Penerj.) Jakarta: Erlangga.

Lupiyoadi, R. (2013). Manajemen Pemasaran Jasa. Jakarta: Salemba Empat.

Nazir, M. (2005). Metode penelitian. Jakarta: Ghalia Indonesia.

Sairdama. (2013). Analisis Pendapatan Petani Kopi Arabika (Coffea Arabica) dan Margim Pemasaran di Distrik Kaти Kabupaten Dogiyai. skripsi, Universitas Satya Wiyata Mandala, Papua.

Tjiptono, F. (2008). Strategi Pemasaran. Yogyakarta: CV Andi Offset.

Zeithaml, V. A., Bitner, M. J., \& Gremler, D. D. (2006). Service Marketting (4th ed). New York: The MC Graww-Hill Companies, Inc. 